IJMS 18 (2), 1-22 (2011)

\title{
ANTECEDENTS AND CONSEQUENCES OF EMPLOYEE LOYALTY TOWARDS THE ORGANIZATION: EMPIRICAL EVIDENCE FROM INDIAN SOFTWARE INDUSTRY
}

\author{
SREEJESH S. \\ TAVLEEN. NAGRA \\ IBS, IFHE \\ University of Hyderabad, India
}

\begin{abstract}
Although substantial differences exists between employee commitment and loyalty, none of the studies made an attempt to understand these constructs separately and analyse the causes and consequences of employee loyalty. In this context, the present study attempts to investigate the antecedents and consequences of employee loyalty in the software industry context. The findings of this paper indicate that employee engagement, satisfaction and commitment have positive and significant impacts on employee loyalty and are considered to be the significant causes for predicting employee loyalty; at the same time the consequences of employee loyalty such as absenteeism and intention to quit do not have any significant effect. However, the study finds that employee satisfaction has a significant effect on the intention to quit via employee absenteeism. The paper shows that, from the managerial perspective, it is necessary for employers and policy-makers to know the causes and consequences of employee loyalty to retain the employees in the long run. The findings of the study suggest that, in order to develop commitment and thereby loyalty, the employer should create a congenial atmosphere for employee engagement and should create satisfied employees. At the same time, this created satisfaction will reduce employee absenteeism and the intention quit. Thus, the attention of the software-employee management should fruitfully focus on the development of employee engagement, satisfaction and commitment, which will ultimately lead to employee loyalty.
\end{abstract}

Keywords: Customer engagement, job satisfaction, commitment, loyalty, absenteeism, intention to quit. 


\section{Introduction}

In recent years, there has been a great deal of enthusiasm for building employee loyalty among employers because of its ability to predict behaviours such as attendance, turnover, and organizational citizenship (Schalk \& Freese, 1997). The concept becomes a central concern as the employers seek assurance that empowered or loyal employees will exercise their discretion in the organization's interests (Tsui, Ashford, Clair \& Xin, 1995; Roehling, Roehling \& Moen, 2001) especially in knowledge-intensive companies. In those companies the knowledge base is important to produce products or services, most work can be said to be intellectual in nature and well-educated; qualified employees form the major part of the work force (Alvesson, 1995; Morris \& Empson, 1998; Starbuck, 1992). Loyalty is not simply grounded in an object's characteristics but in some relational connection. Therefore, building the relationship between employer and employee is very important to build loyalty in an organization. Loyalties develop over time in an organization because of the continuity of overlapping, shared experiences of the same places or persons or events. A truly loyal employee in an organization does not act merely in order to promote personal benefits. Such an employee has the employer's or the organization's best interest at heart, and strives to promote that interest (Michalos, 1981).

The definitions of loyalty range from specific to broad and such large variations in definition of loyalty makes it difficult to determine and measure what actually loyalty is. Also it becomes difficult to analyse the antecedents and consequences of employee loyalty (Coughlan, 2005). Loyalty has been defined as "employee's feeling of attachment to an organization" (Hirschman, 1970). Logan (1984) defined a loyal employee as one who did not accept a position with another organization. Dooley and Frynell (1999) describe loyalty as "disinclination toward opportunism". The concept of loyalty has been loosely defined and the literature is mixed and inconclusive regarding the differences between loyalty and commitment. Allport (1933) categorized three elements of loyalty-voluntary nature, demand for ongoing adherence, and its grounding in morality differentiates it from commitment (Coughlan, 2005). Morrow (1983) is of the opinion that, though loyalty and commitment have much in common much is lost when both are used interchangeably. Although loyalty is difficult to quantify, the behaviour consistent with loyalty can be measured, for example offers passed on to the others (Sajven, 2007). Loyalty describes "constancy, fidelity and devotion". Loyalty does not encourage exit as an option even when an employee has attractive offers. (Hirschman, 1992). It has been defined in either- 
or terms, that is, either an employee is loyal or not. This dichotomous approach provides scope for further investigation into loyalty. The term loyalty connotes different meanings to different people (Hart \& Thompson, 2007). Although both the terms have been used as synonyms, both are different at least in two ways. Commitment towards an organization is a matter of personal choice - whether to commit or not based on rational judgment. Loyalty includes a normative component that is, it is an obligation or duty. Commitment is unidirectional, that is commitment is measured as the extent to which an employee is committed; however loyalty is mutual; loyalty comes out of relationships. However commitment still remains an important element of loyalty (Hart \& Thompson, 2007). Hart and Thompson in their study applied three distinct forms of commitment to loyalty and then defined loyalty. Loyalty to one's employer may come from a genuine desire to maintain the relationship even in adversities (affective component); costs of disloyalty would be more (continuance component); one has to be loyal because it is a duty to remain loyal (normative). Using these three dimensions they defined loyalty as "An individual's perception that both the parties to a relationship have fulfilled reciprocal expectations that (a) denote enduring attachment between two parties, (b) involve self-sacrifice in the face of adversities, and (c) are laden with obligations of duty".

The purpose of this study is to investigate the antecedents and consequences of employee loyalty in the software industry context. The extant literature in employee loyalty considered commitment and loyalty as synonyms, and studied the commitment/loyalty of employees towards the boss (e.g. Zhen Xiong Chen et al., 2002). Thus it is worthwhile to differentiate the construct of commitment from loyalty and analyse the causes and consequences of the employee's loyalty in the software context. However, there are no studies to date that have investigated the antecedents and consequences of employee loyalty. As far as we are aware, this is the first article to examine employee commitment and loyalty as separate constructs and examine the antecedents and consequences of employee loyalty in the software industry.

The paper is organized as follows. The first section develops a conceptual model of the causes and the consequences of an employee's loyalty in the software industry. The second section carries the research design, which explains the methods, the measures and the sample. The third part of the study discusses the analysis and the results. The paper concludes with the discussion, the implications and the directions for future research. 


\section{Conceptual Model Development}

In this section, the study develops a conceptual model of the causes and the consequences of an employee's loyalty in the software industry (see Figure 1). The study captures the employee's engagement, satisfaction, and commitment as antecedents of employee loyalty and its behavioural outcomes like absenteeism and intention to quit as the consequences, which are the centre stage of the discussion. The objective has been to develop an improved understanding of not only the constructs themselves, but also how they relate to each other and subsequently leads to behavioural outcomes.

\section{Employee Engagement as a Driver of Employee Commitment and Job Satisfaction}

The extent literatures have provided a number of definitions for employee engagement. Khan (1990) defined personal engagement as 'the harnessing of organization members' selves to their work roles. In engagement, people employ and express themselves physically, cognitively, and emotionally during role performances". Maslach, Schaufeli and Leiter, (2001) defined engagement as characterized by energy, involvement and efficacy; the direct opposite of the three burnout dimensions of exhaustion, cynicism, and inefficacy. In an operational point of view engagement can be defined "as a positive, fulfilling, work-related state of mind that is characterized by vigour, dedication, and absorption" (Schaufeli, Salanova, Gonzalez-Roma \& Bakker, 2002). Employee engagement is considered to be the mediating variable for the relationship between constructs such as job satisfaction and commitment (Maslach et al., 2001). Engagement has been a crucial factor, which is positively related to organizational commitment and loyalty, and negatively related to intention to quit from that organization (Schaufeli \& Bakker, 2004; Sonnentag, 2003). However, there are some researches which found the relation among engagement and many other constructs in the organizational science literature. For example, the meta-analysis of the association between job satisfaction and affective commitment reveals a correlation of 65 (Meyer, Stanley, Herscovitch \& Topolnytsky, 2002). Such levels of association still leave room for differential relationships with other outcome variables of interest and can add to our understanding of organizational phenomena. Nonetheless, as a relatively new construct, more work establishing the validity, differential antecedents and differential outcomes associated with engagement is warranted (Gruman \& Alan, 2011). Therefore, it is hypothesized that:

4 IJMS 18 (2), 1-22 (2011) 
Hypothesis 1: Employee engagement has a positive impact on employee commitment.

Hypothesis 1a: Employee engagement has a positive impact on employee loyalty.

Hypothesis 1b: Employee engagement has a positive impact on employee job satisfaction.

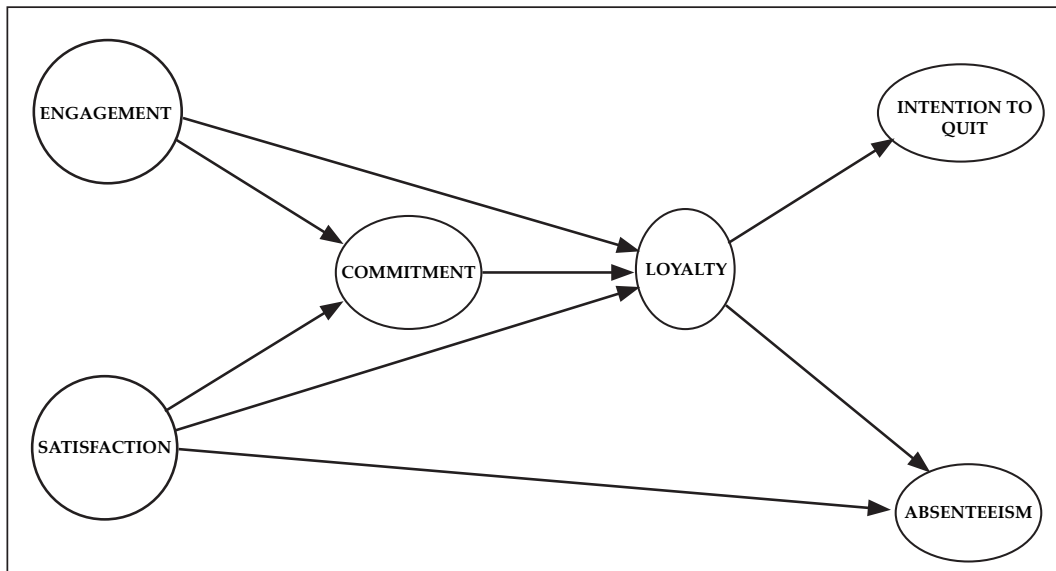

Figure 1. The model of antecedents and consequences of employee loyalty.

\section{Employee Job Satisfaction as a Driver of Employee Commitment and Loyalty}

The concept of job satisfaction can be defined as a positive emotional state that generates an affective response to the job situation (Locke, 1984). Organizational commitment can be defined as a psychological state that binds an employee to an organization (Jafri, 2010). There are three main theoretical perspectives existing in the area of satisfactioncommitment relationship. First, commitment to the company develops from job satisfaction such that commitment mediates the effects of satisfaction on withdrawal variables. The second perspective holds that the direction of influence between satisfaction and commitment is the reverse of that above. The third view holds that both satisfaction and commitment contribute uniquely to the turnover process. Bhagat and Chassie (1981) studied five aspects of satisfaction and suggested that satisfaction with promotional characteristics was an important contributor to organizational commitment. Satisfaction with promotion is an important element in organizational commitment of men workers (Welsch \& La Van, 1981) as well as overall job and work satisfaction (Bluedom, 1982). 
Other than commitment and loyalty, the literature says job satisfaction has two important outcomes; absenteeism and turnover. There are research findings that linked job satisfaction to absenteeism (e.g. Hackett \& Gyion, 1985; Brook \& Price, 1989). Baker (2010) found that job satisfaction has a direct effect on absenteeism, while indirectly affecting turnover or switching through absenteeism.

Hypothesis 2: Employee satisfaction has a positive impact on employee commitment.

Hypothesis 2a: Employee satisfaction has a positive impact on employee loyalty.

Hypothesis 2b: Job satisfaction has a direct effect on employee absenteeism.

Hypothesis 2c: Job satisfaction has only an indirect effect (IE) on job quitting through absenteeism.

\section{Commitment as a driver to loyalty}

Meyer and Allen (1997) defined commitment as a multidimensional construct consisting of three dimensions in the organizational context. These three dimensions of the construct are the affective (affective attachment to the organization), continuance (perceived costs associated with leaving the organization) and normative (feelings of obligation toward the organization) dimensions. Bansal, Gregory \& Shirley (2004) extended Meyer and Allen's (1997) threecomponent model of organizational commitment. The authors defined commitment as a force that binds an individual to continue to purchase services (i.e. not to switch) (Bansal et al., 2004). Employees with strong affective bonds stay with the organization because they want to. Those with strong continuance commitment remain because they feel they have to. Normatively-committed employees stay because they feel they ought to. Affective commitment develops when the employees become involved in, recognize the value-relevance of, and/or derive their identity from, an association with the organization. Normative commitment develops when employees internalize the organizational norms through socialization; receive benefits that induce them to feel the need to reciprocate and/or to accept the terms of a psychological contract (Rousseau, 1995). Continuance commitment develops when the employees perceive that there are no alternatives other than to remain in the current organization. Research has shown significant interest in studying commitment as a major predictor of various matrices related to retention, particularly switching/staying intentions and repurchase intentions (Bansal et al., 2004; Fullerton, 2003; Venetis \& Ghauri,2004; Jones et. al., 2007). As a

6 IJMS 18 (2), 1-22 (2011) 
construct it describes an attitude that reflects the desire to maintain a valued relationship (Moorman, Zaltman \& Deshpande, 1992; Bansal et. al., 2004).

Meyer and Herscovitch (2001) stated that maintaining the relationship with a target or organization is the focal outcome associated with commitment. Most of the definitions in organizational commitment literature state that commitment is the existence of a psychological bond between the individual and the organization. Such a bond includes concepts as the readiness to expend energy, loyalty and work toward the organization's goals, the unwillingness to leave for rewards that may be greater elsewhere, a sense of oneness to the organization, a positive valuation of the organization, or acceptance of and identification with the organization's values and goals(Chusmir,1988). Passiante (2006) stated that commitment affects loyalty. In the present study, commitment can be stated as an employee's psychological attachment to the organization that develops before the employee determines to stay in the organization from a sense of loyalty.

Hypothesis 3: Employee commitment has a positive impact on employee loyalty.

Hypothesis 3a: Employee loyalty has a negative impact on employee absenteeism.

Hypothesis 3b: Employee loyalty has a negative impact on employee's intention to quit.

\section{Research Design}

\section{Method}

The present study applies the PLS structural equation modelling (SEM) to estimate the theoretical model using the software programme SmartPLS( Ringle, Wende \& Will, 2005). Many of the extant literatures suggested PLS (Wold, 1975) as the suitable method for estimating complex models. This suggestion was based on the grounded argument that other widely acceptable techniques that are used to estimate the relationship among the latent variables; especially the co-variance-based SEM introduced by Joreskog (1973) exemplified by many available software programmes, including LISREAL (Joreskog \& Sorbom, 1993), AMOS (Arbuckle, 1994), EQS (Bentler, 1995) and Mplus (Muthen \& Muthen, 1994) make more strict assumptions on the data. At the same time, Fornell and Bookstein (1982) suggested two main problems associated with the co-variance-based SEM technique: 


\section{(1) Improper Solutions}

(i.e. solutions outside the admissible parameter space). The term improper solution describes several possible problems with model estimation, ranging from model non-convergence to invalid values for parameter estimates. Non-convergence in estimation occurs when the maximum likelihood process cannot find a minimum-fit function. Usually the estimated model does not converge because of very serious mistakes in how the model is specified. Hsu et al. (2006) suggested several reasons for improper solutions: (a) the theory is wrong, (b) the data are inaccurate, (c) the sample size is too small, or (d) the covariance structure analysis is not appropriate for the analysis task (Fornell \& Bookstein, 1982; Gerbing \& Anderson, 1987).

\section{(2) Factor Indeterminacy}

Therefore, PLS was considered to be the suitable technique for general SEM purposes. There are several reasons for the widespread use of PLS for measuring customer satisfaction. These are, (a) PLS is not based on any strict assumption about the data, especially the assumption of normality (Ferreira, 2010); (b) PLS is best suited for predictive purposes (Chin, 1998, Ferreira, 2010); (c) it is more efficient in small sample size as well; (d) it avoids the indeterminacy problem (Hulland, 1999; Ferreira, 2010); and (e) works with both formative and reflective indicators (Ferreira, 2010).

Hermon Wold (1966) was the first person who introduced the idea of partial least squares in psychometric literature through his famous book "Estimation of principal components and related models by iterative least squares". However, the application of this in path models with latent variables was published by World in 1979 and then the main references on the PLS algorithm are World 1982, 1985(Tenenhaus et al., 2005).

The partial least square method is a two-step procedure:

In the first step, latent variable scores are computed using the PLS algorithm. In this, a measurement model is conducted using the measurement variables to their own latent variable and this measurement model, also known as the outer model, can be expressed as:

$$
Y_{j}=\lambda_{y j} \eta_{j+} \xi_{j}
$$

Here $Y_{j}$ is the column vector of the centred manifest variables and $\eta_{j}$ the dependent latent variable.

8 IJMS 18 (2), 1-22 (2011) 
In the second step, OLS regressions are run on the latent variable scores for estimating the structural equations. This is called the structural model or the inner model, because a structural model is run relating some endogenous latent variables to other latent variables. If $\eta$ is the column vector consisting of $\mathrm{p}$ the endogenous latent variables, and $\xi$ a column vector consisting of q exogenous latent variables, the structural model connecting vector $\eta$ to the vectors $\eta$ and $\xi$ can be written as:

$$
\eta=\beta \eta+\Gamma \xi+\zeta
$$

Here $\beta$ is a zero-diagonal $p \times p$ matrix of regression coefficients, $\Gamma$ a $p$ $x \mathrm{q}$ matrix of regression coefficients and $\zeta$ is a centred random vector of dimension $\mathrm{p}$.

\section{Measures}

The study used the multi-item scale developed by Saks (2006) to measure employee engagement and was measured in a 6-point agreement scale $^{1}$ ( $1=$ strongly disagree to $6=$ strongly agree) in all cases. In this, items were included to measure the employee's job engagement and organization engagement. The three-item employee job satisfaction measure was adopted from the work of Cammann et al. (1983). Employee commitment was measured by six items adopted from Rhoades et al. (2001), using a Likert scale of six (1=totally disagree to $6=$ totally agree). The construct of loyalty has been operationalized through using a six-item scale by De Ruyter et al. (1998). Intention to quit was measured by Colarelli's (1984) three-item scale. Absenteeism was measured by the absence frequency data. Absence frequency was more strongly related to satisfaction than absence duration (Vroom, 1964). (See Table 4 for a description of the data collection instrument). After the preparation of the questionnaire, the study conducted a pretest, using an interview with 20 software professionals. From the pretesting it was found that there was no problem in the questionnaire design, content, format and wording.

\section{Research Setting and Subjects}

The hypotheses were tested using a closed-ended survey in four different software companies in India. These companies were selected in part due to relative ease of data collection and their emerging roles in the software field. Although, the study used convenience sampling for the selection of the samples, an attempt was made to randomize 
data collection in terms of time and company, which would ultimately reduce sampling and response bias. For achieving this objective the data were collected at different times of the day, from these four different software companies. Data were collected during January 2010 via structured interviews. 203 employees participated in the survey. Of the sample, 95 were females and the remaining were males and their ages ranged from 26 to 49 years.

\section{Analysis and Results}

\section{Measurement model evaluation}

The present study conducted a preliminary analysis to examine the psychometric properties of the scales through measures of central tendency, dispersion, factor loadings, bivariate Pearson correlations and construct and discriminant validity. The correlation matrix of all the latent variables in Table 1 were used in Figure 1. All the estimated correlations were statistically significant at $\mathrm{p}<0.001$.

Table 1

Latent Variable Correlations

\begin{tabular}{lccccc}
\hline & Absenteeism & Commitment & Engagement & Loyalty & $\begin{array}{c}\text { Intention } \\
\text { to Quit }\end{array}$ Satisfaction \\
\hline Absenteeism & & & & & \\
Commitment & $0.269876^{*}$ & & & & \\
Engagement & $-0.001266^{*}$ & $0.231379^{*}$ & & & \\
Loyalty & $-0.029061^{*}$ & $0.321350^{*}$ & $0.895029^{*}$ & & \\
Intention to & $0.920306^{*}$ & $0.259287^{*}$ & $0.007579^{*}$ & $-0.031913^{*}$ & \\
Quit & & & & & \\
Satisfaction & $0.458247^{*}$ & $0.671428^{*}$ & $0.038724^{*}$ & $0.068527^{*}$ & $0.445604^{*}$ \\
\hline
\end{tabular}

*shows significant at $1 \%$ level.

Before assessing the hypothesized relationship, the study assessed dimensionality, reliability and validity using the measurement model analysis (Bentler, 1995). Reliability is considered to be the indicator of convergent validity (Hair et al., 2009). For checking reliability, the study measured internal consistency through Cronbach's (1954) Coefficient alpha and construct reliability through assessing the outer \& inner models. The Coefficient alpha of each construct exceeded the cut-off level of 0.40 for all latent variables (see Table 2).

10 IJMS 18 (2), 1-22 (2011) 
Even though Coefficient alpha is a commonly used measure it may underestimate reliability (Hair et al., 2009). Therefore the study calculated composite reliability through PLS (see Table 2). It is usually computed from the squared sum of factor loadings for each construct and the sum of the error variance terms for a construct. A reliability estimate which is 0.7 or higher suggests good reliability (Bagozzi \& $\mathrm{Yi}, 1988$ ). Another set of measures that represent convergent validity is the Average Variance Extracted (AVE) (see Table 2). An AVE of .4 or higher suggests adequate measure of convergence. For each set of factors, the standardized loadings were found to be higher than the recommended 0.5 cut-off and were statistically significant at the .05 level which confirms convergent validity (Baggozzi \& Yi, 1988; Hair et al., 2009) (See Table 4). Table 4 shows the standardized loading estimates (outer model or measurement model). All the loadings were found to be significant at the .05 level.

The best way of assessing discriminant validity is to compare the variance extracted percentages of any two constructs with the square of the correlation estimate between these two constructs. If the variance-extracted is greater than the squared correlation estimate it provides evidence of discriminant validity (Fornell \& Larcker, 1981; Hair et al., 2009). The basic idea behind this analysis is that a latent variable should share more variance with its assigned indicators than with any other latent variables. (See Table 2). In the study it is clear that the constructs confirm both the convergent and discriminant validity.

Table 2

Reliability, Average Variance Extracted and Discriminant Validity

\begin{tabular}{lcccccccc}
\hline Construct & $\begin{array}{c}\text { Cronbach } \\
\text { Alpha }\end{array}$ & $\begin{array}{c}\text { Composite } \\
\text { Reliability }\end{array}$ & 1 & 2 & 3 & 4 & 5 & 6 \\
\hline Engagement (1) & 0.898 & 0.918 & 0.584 & & & & & \\
Satisfaction (2) & 0.800 & 0.879 & 0.001 & 0.709 & & & & \\
Commitment (3) & 0.624 & 0.732 & 0.053 & 0.450 & 0.411 & & & \\
Loyalty (4) & 0.761 & 0.847 & 0.801 & 0.004 & 0.103 & 0.582 & & \\
Intention to Quit (5) & 0.861 & 0.914 & 0.001 & 0.198 & 0.067 & 0.001 & 0.781 & \\
Absenteeism (6) & --- & --- & 0.001 & 0.209 & 0.072 & 0.001 & 0.846 & 1.000 \\
\hline
\end{tabular}

Note. Diagonal represents the average Variance extracted (AVE), while off-diagonal elements represent the squared correlation between the latent variables.

IJMS 18 (2), 1-22 (2011) 11 
Table 3

$R^{2}$ Values for the Latent Constructs

\begin{tabular}{ll}
\hline Constructs & R square \\
\hline Absenteeism & 0.213663 \\
Commitment & 0.493060 \\
Engagement & 0 \\
Loyalty & 0.818845 \\
Quit & 0.846990 \\
Satisfaction & 0.001500 \\
\hline
\end{tabular}

Table 4

Descriptive Statistics and Factor Loadings of the Items

\begin{tabular}{ccc}
\hline Items & Mean SD $\begin{array}{c}\text { Factor } \\
\text { Loadings }\end{array}$ \\
\hline
\end{tabular}

Employee engagement

(EN1)I really "throw" myself into my job. $\quad 5.00 \quad 1.12 \quad 0.788$

(EN2)Sometimes I am so involved my job that I lose $\begin{array}{llll}4.88 & 1.11 & 0.774\end{array}$ track of time.

(EN3)This job is all consuming; I am totally into it. $\quad \begin{array}{llll}4.81 & 1.04 & 0.797\end{array}$

$\begin{array}{lllll}\text { (EN4)My mind often wanders and I think of other } & 4.86 & 1.13 & 0.713\end{array}$ things when doing my job (R).

(EN5)I am highly engaged in this job. *

(EN6)Being a member of this organization is very $4.61 \quad 1.21 \quad 0.796$ captivating.

(EN7)One of the most exciting things for me is $4.61 \quad 1.09 \quad 0.743$ getting involved with things happening in this organization.

(EN8)I am really not into the "goings-on" in this $4.34 \quad 1.05 \quad 0.741$ organization.

$\begin{array}{llll}\text { (EN9)Being a member of this organization makes me } & 4.53 & 1.21 & 0.758\end{array}$ come alive.

(EN10)Being a member of this organization is exhilarating for me*.

(EN11)I am highly engaged in this organization*.

(continued)

12 IJMS 18 (2), 1-22 (2011) 


\begin{tabular}{|c|c|c|c|}
\hline Items & Mean & SD & $\begin{array}{l}\text { Factor } \\
\text { Loadings }\end{array}$ \\
\hline \multicolumn{4}{|l|}{ Iob satisfaction } \\
\hline (JS1)All-in-all, I am satisfied with my job. & 4.76 & 1.36 & 0.849 \\
\hline (JS2)In general, I do not like my job (R). & 4.64 & 1.27 & 0.797 \\
\hline (JS3)In general, I like working here. & 4.64 & 1.27 & 0.878 \\
\hline \multicolumn{4}{|l|}{ Organizational commitment } \\
\hline \multicolumn{4}{|l|}{$\begin{array}{l}\text { (OC1)I would be happy to work in my organization } \\
\text { until I retire*. }\end{array}$} \\
\hline \multicolumn{4}{|l|}{$\begin{array}{l}\text { (OC2)Working in my organization has a great deal of } \\
\text { personal meaning to } \mathrm{me}^{*} \text {. }\end{array}$} \\
\hline $\begin{array}{l}\text { (OC3)I really feel that problems faced by my } \\
\text { organization are also my problems. }\end{array}$ & 4.67 & 1.22 & 0.778 \\
\hline $\begin{array}{l}\text { (OC4)I feel personally attached to my work } \\
\text { organization. }\end{array}$ & 4.04 & 1.09 & 0.571 \\
\hline $\begin{array}{l}\text { (OC5)I am proud to tell others I work in my } \\
\text { organization. }\end{array}$ & 4.24 & 1.15 & 0.627 \\
\hline $\begin{array}{l}\text { (OC6)I feel a strong sense of belonging to my } \\
\text { organization. }\end{array}$ & 3.81 & 1.35 & 0.563 \\
\hline \multicolumn{4}{|l|}{ Intent to quit } \\
\hline (IQ1)I frequently think of quitting my job. & 4.73 & 1.29 & 0.921 \\
\hline $\begin{array}{l}\text { (IQ2)I am planning to search for a new job during the } \\
\text { next } 12 \text { months. }\end{array}$ & 4.70 & 1.17 & 0.888 \\
\hline $\begin{array}{l}\text { (IQ3)If I have my own way, I will be working for this } \\
\text { organization one year from now (R). }\end{array}$ & 4.65 & 1.10 & 0.839 \\
\hline \multicolumn{4}{|l|}{ Employee loyalty } \\
\hline $\begin{array}{l}\text { (LY1) I would definitely recommend the job of } \\
\text { company " } \mathrm{X}^{2 \prime} \text { to someone who seeks my } \\
\text { advice. }\end{array}$ & 4.27 & 1.16 & 0.774 \\
\hline $\begin{array}{l}\text { (LY2) I encourage relatives and friends to work with } \\
\text { company " } X^{\prime} \text {. }\end{array}$ & 4.39 & 1.21 & 0.679 \\
\hline \multicolumn{4}{|l|}{$\begin{array}{l}\text { (LY3)I intend to stay in company " } \mathrm{X} \text { " for the next few } \\
\text { years". }\end{array}$} \\
\hline \multicolumn{4}{|l|}{$\begin{array}{l}\text { (LY4)I say positive things about company " } \mathrm{X} \text { " to } \\
\text { others". }\end{array}$} \\
\hline $\begin{array}{l}\text { (LY5) I consider company " } \mathrm{X} \text { " as my first choice to } \\
\text { work with. }\end{array}$ & 5.00 & 1.12 & 0.801 \\
\hline $\begin{array}{l}\text { (LY6)I would continue to work with company " } \mathrm{X} \text { " } \\
\text { even if another company offers an increased } \\
\text { amount. }\end{array}$ & 4.88 & 1.11 & 0.792 \\
\hline
\end{tabular}

IJMS 18 (2), 1-22 (2011) 13 

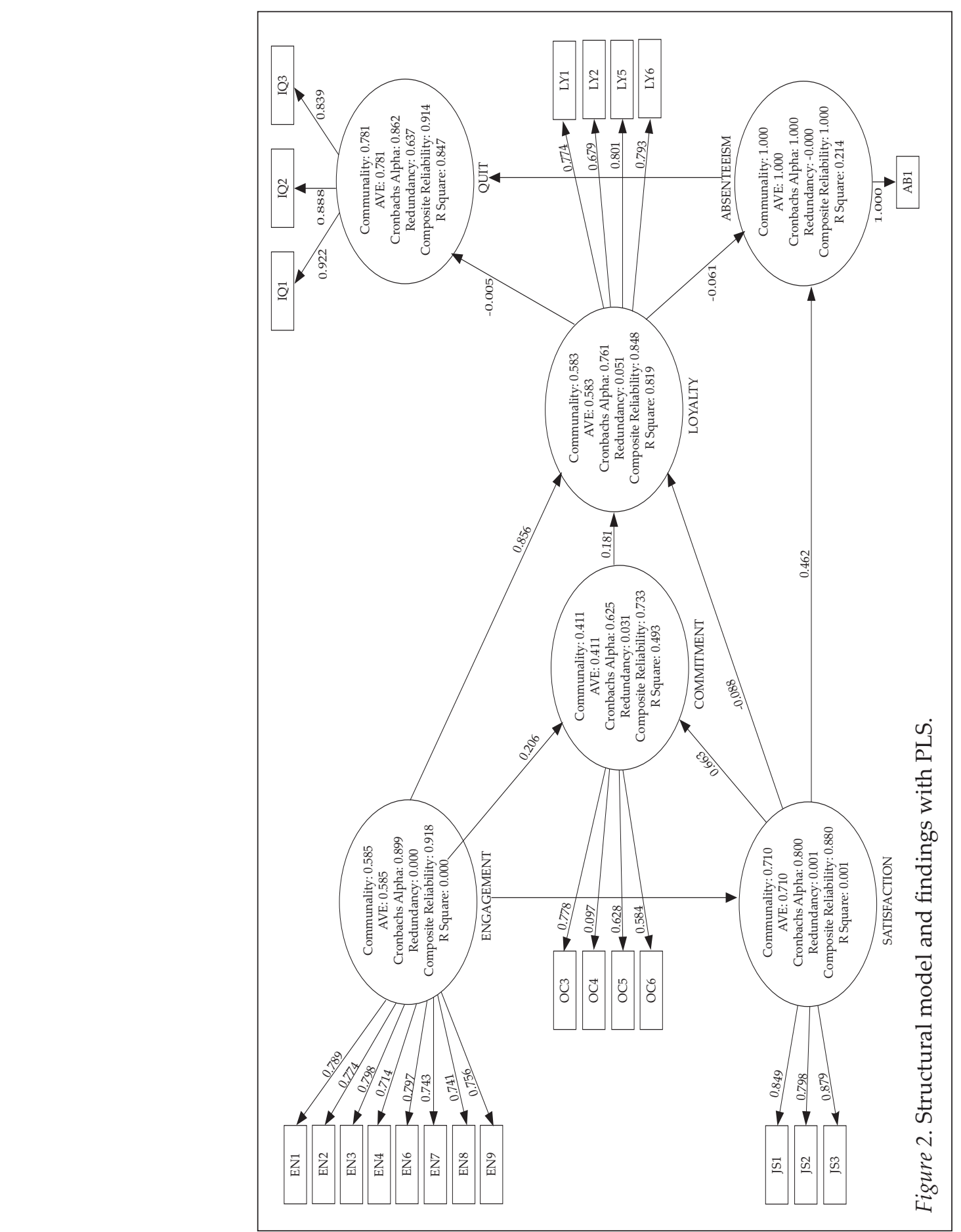

14 IJMS 18 (2), 1-22 (2011) 


\section{Testing the Hypotheses}

Table 3 shows $R^{2}$ values for the latent variables, which show the percentages of explained variance for the latent variables. The values for job satisfaction, employee commitment, employee loyalty, absenteeism and intention to quit are $0.001,0.49,0.81,0.21$, and 0.84 respectively. From the study it is evident that the percentage of variance explained by employee loyalty is $81 \%$, which is considered to be very satisfactory. The study applied a non-parametric bootstrapping procedure $^{3}$ (300 subsamples; 500 cases; no sign change) to evaluate the significance of the path coefficients (Davison \& Hinkley, 1997; Henseler, Ringle \& Sinkovics, 2009; Volckner et al., 2010).

Table 5

Structural Parameter Estimates

\begin{tabular}{lc}
\hline Paths & Estimates (T-Values) \\
\hline Engagement -> Commitment & $0.205^{* *}(1.76)$ \\
Engagement -> Loyalty & $0.856^{* * *}(25.55)$ \\
Engagement -> Satisfaction & $0.038 \mathrm{~ns}(0.77)$ \\
Satisfaction -> Absenteeism & $0.462^{* * *}(4.22)$ \\
Satisfaction -> Commitment & $0.663^{* * *}(4.22)$ \\
Satisfaction -> Loyalty & $0.086^{* * *}(2.16)$ \\
Absenteeism -> Intention to Quit & $0.920^{* * *}(101.11)$ \\
Commitment -> Loyalty & $0.181^{* * *}(2.10)$ \\
Loyalty -> Absenteeism & $-0.060 \mathrm{~ns}(0.98)$ \\
Loyalty -> Intention to Quit & $-0.005 \mathrm{~ns}(0.21)$ \\
\hline
\end{tabular}

*** Significant at the $p<.01$ level.

** Significant at the $\mathrm{p}<.05$ level. ns: not significant.

In Hypotheses $1-1 b$, the study postulates that employee engagement has a positive effect on employee commitment, loyalty and satisfaction. The impact of employee engagement on the other dimensions is positive and significant in most of the cases $(\mathrm{p}<.05)$. The only path for which we find no support is from employee engagement to satisfaction (Hypothesis 1b). Thus the results provide full support for Hypothesis 1 and 1a, and no support for $1 \mathrm{~b}$. 
With Hypothesis 2-2c, the study investigated the direct effect of satisfaction on three other dimensions like absenteeism, commitment and loyalty, and indirect effect of satisfaction on intention to quit through absenteeism. The results provided full support for all the four hypotheses; satisfaction has a direct positive impact on commitment $(\beta=0.663 ; p<.01)$, loyalty $(\beta=0.086 ; p<.01)$, absenteeism $(\beta=0.462 ; p<.01)$ and indirect impact on intention to quit via absenteeism $(\beta=0.920$; $\mathrm{p}<.01)$.

Finally, the study proposes in Hypotheses 2-3b that employee commitment influences loyalty with the organization and the impact of loyalty with absenteeism and the intention to quit, and the study found that employee commitment has a strong positive impact on its employee's loyalty $(\beta=0.181 ; p<.01)$ and the other two hypotheses are not supportive.

\section{Discussion, Implications and Recommendations for Further Research}

The preliminary results of this research provided evidence that employee engagement, satisfaction and commitment have positive and significant impacts on employee loyalty and are considered to be the significant causes for predicting employee loyalty, but at the same time the consequences of employee loyalty such as absenteeism and intention to quit do not have any significant effect. This indicates that causes like engagement, satisfaction and commitment are very important for predicting employee loyalty and employee loyalty does not directly lead to any outcome or consequences; instead the absence of satisfaction will lead to absenteeism and intention to quit. Taken together, the study results offer strong support for satisfaction for predicting absenteeism, commitment and loyalty. Thus, employers and researchers should focus more on the importance of employee satisfaction for creating loyal employees.

From the result, it is evident that employee job satisfaction is able to predict employee absenteeism and the intention to quit decision (via absenteeism) and supports the extant literature (e.g. Hackett \& Guion, 1985; Brook \& Price, 1989). However, different from earlier literature, employee loyalty was found to be an insignificant predictor for employee absenteeism and turnover decision. This shows the true picture of a knowledge intensive industry that, if an employee is loyal it does not guarantee that he or she will exit or stay in the company, but satisfaction level (job satisfaction) might decide the 
staying and quitting decision. Ultimately from the study we infer that in a knowledge-based industry job satisfaction is the major factor that determines the employee-switching or staying decision than loyalty towards the organization. The employee would be loyal to that organization, for different reasons, but if at all he or she is not satisfied with the job, ultimately it will lead to job-switching or quitting.

From the managerial perspective, the model developed and used in this research will be very useful for employers and policy makers as a tool to determine the key factors of employee loyalty. It is also necessary to know the relationship between employee engagement, satisfaction and commitment on employee loyalty, because the influence on these three dimensions are different on employee loyalty. It is of paramount importance of software companies to develop loyal employees, because these companies face employee switching and absenteeism each and every day. Thus, management's attention might be fruitfully focused on the development of such committed and loyal employees. In other words, the software companies should create a congenial atmosphere for employee engagement which would lead to satisfied employees and ultimately commitment and loyalty. Of course, the more loyal the employees in the organization, the greater is the possibility of their outcome and lesser is the expense for new employee training and development.

Additionally, given the nature of the sample, the research is limited to the Indian software industry. Further research would be necessary by extending the model to different industries and to different countries by exploring the research variables and the other variables which are not mentioned in depth in this research.

\section{End Notes}

1. The study used the 6-point likert scale to avoid neutral opinions from the respondents.

2. Note: in the questionnaire company " $X$ " was replaced by the name of the company in which the employee works.

*items was deleted because it has low factor loadings of less than 0.50 (Hair et al., 1995)

EN=Engagement; JS=Job Satisfaction; OC=Organizational Commitment; IQ=Intent to quit; LY=Employee loyalty

3. In PLS path modelling non-parametric bootstrapping can be used to provide confidence intervals for all parameter estimates, which help the basis for statistical inference. This bootstrapping 
technique provides an estimate of the shape, spread, and bias of the sampling distribution of a specific statistics. In this, the observed sample treats it as if it represents the population. The bootstrapping analysis allows for the statistical testing of the hypothesis $\mathrm{H}_{0}: \mathrm{w}=0(\mathrm{w}$ can be any parameter estimated by PLS) against the alternative hypothesis $\mathrm{H}_{1}: \mathrm{w} \neq 0$ at $\mathrm{m}+\mathrm{n}-2$ degrees of freedom (where $m$ is the number of PLS estimates for $\mathrm{w}$ in the original sample, which is $1 ; \mathrm{n}$ is the number of bootstrap estimates for $\mathrm{w}$ ). The PLS results for all bootstrap samples provide the mean value and standard error for each path model coefficient. This information permits a student's t-test to be performed for the significance of path model relationships. (To know more about PLS bootstrapping refer to Davison and Hinkley, 1997).

\section{References}

Alvesson, M. (1995). Management of knowledge-intensive companies. Berlin/New York: de Gruyter.

Allport, F. H. (1933). Institutional behavior. Chapel Hill, NC: University of North Carolina Press.

Arbuckle, J. (1994). AMOS: Analysis of moment structures. Psychometrika, 59(1), 135-37.

Bagozzi, R. R., \& Yi, Y. (1988). On the evaluation of structural equation models. Journal of the Academy of Marketing Science, 16(1), 74-94.

Bentler, P. M. (1995). EQS: Structural equations program manual. Encino, CA: Multivariate Software.

Bhagat, Rabi S., \& Marilyn, B. C. (1981). Determinants of organizational commitment in working women: Some implications for organizational integration. Journal of Occupational Behavior, 2(1), $17-30$.

Bluedorn, A. C. (1982). A unified model of turnover from organizations. Human Relations, 35, 135-153.

Brooke, P. P., \& Price, J. L. (1989). The determinants of employee absenteeism: An empirical test of a causal model. Journal of Occupational Psychology, 62, 1-19.

Bansal, H. S., Gregory Irving, P., \& Shirley F. T. (2004). A three component model of customer to service providers. Journal of the Academy of Marketing Science, 32(3), 234-250.

Baker, W. K. (2010). Antecedents and consequences of job satisfaction: Testing a comprehensive model using integrated methodology. Journal of Applied Business Research, 20(3).

Coughlan, R. (2005). Employee loyalty as adherence to shared moral values. Journal Managerial Issues, XVII(1), 4-5.

18 IJMS 18 (2), 1-22 (2011) 
Cronbach, I. J. (1954). Report on a psychometric mission to clinician. Psychometrika, 19, 263-270.

Chusmir, L. H. (1988). Religious attitudes toward work: A new look at an old question. Journal of Organizational Behaviour, 9, 251-262.

Chin, W. W. (1998). The partial least squares approach for structural equation modeling. In G. A. Marcoulides (Ed.), Modern Methods for Business Research (pp. 295-336). London: Lawrence Erlbaum Associates.

Cammann, C., Fichman, M., Jenkins, G. D., \& Klesh, J. R. (1983). Assessing the attitudes and perceptions of organizational members. In S.E. Seashore, E.E. Lawler, P. H. Mirvis (Eds.), \& Cammann, C. (Eds), Assessing organizational change: A guide to methods, measures, and practices (pp. 71-138). New York: John Wiley \& Sons.

Colarelli, S. M. (1984). Methods of communication and mediating processes in realistic job previews. Journal of Applied Psychology, $69,633-42$.

Coughlan, R. (2005). Employee loyalty as adherence to shared moral values. Journal of Managerial Issues, 17(1), 43-57.

Dooley, R. S., \& Fryxell, G. E. (1999). Attaining decision quality and commitment from dissent: The moderating effects of loyalty and competence in strategic decision-making teams. Academy of Management Journal, 42, 389-402.

Fornell, C., \& Larcker, D. F. (1981). Evaluating structural equation models with unobservable variables and measurement error. Journal of Marketing Research, 48, 39-50.

Fornell, C., \& Bookstein, F. L. (1982). Two structural equation models: LISREL and PLS applied to consumer exit-voice theory. Journal of Marketing, 19, 440-452.

Fullerton, G. (2003). When does commitment lead to loyalty? Journal of Service Research, 5(4), 333-45.

Ferreiraa, I., Jose, C., \& Pedro Saraivac. (2010). An integrated framework based on the ECSI approach to link mould customers' satisfaction and product design. Total Quality Management, 21(12), 1383-1401.

Gerbing, D. W., \& Anderson, J. C. (1987). Improper solutions in the analysis of covariance structures: Their interpretability and a comparison of alternate re-specifications. Psychometrika, 52, 99-111.

Hirschman, A. O. (1970). Exit, voice, and loyalty. Cambridge, Mass.: Harvard University Press.

Jöreskog, K. G. (1973). A general method for estimating a linear structural equation system. In A. S. Goldberger, \& O. D. Duncan (Eds.), Structural equation models in the social sciences (pp. 85-112). New York: Academic Press. 
Jöreskog, K. G., \& Sörbom, D. (1993). New features in PRELIS2. Chicago: IL, Scientific Software International.

Jafri Mohd. Hassan. (2010). Organizational commitment and employee's innovative behavior: A study in retail sector. Journal of Management Research, 10 (1).

Jones, T., \& Shirley, F. T. (2007). The nature and dimensionality of service loyalty: How many dimensions? Journal of Services Marketing, 27 (1), 36-51.

Hackett, R.D., \& Guion R.M. (1985). A reevaluation of the absenteeismjob satisfaction relationship. Organizational Behavior and Human Decision Processes, 35, 340-381.

Hsu, Sheng-Hsun, Wun-Hwa Chen \& Ming-Jyh Hsieh. (2006). Robustness testing of PLS LISREL, EQS and ANN-Based SEM for measuring customer satisfaction. Total Quality Management, 17(3), 355-371.

Hair, J. F., J., Anderson, R. E., Tatham, R. L., \& Black, W. C. (2009). Multivariate data analysis (6th. ed.). Englewood Cliffs, NJL: Prentice Hall.

Hart, D.W., \& Thompson, J. A. (2007). Untangling employee loyalty: A psychological contract perspective. Business Ethics Quarterly, 17, 297-323.

Kahn, W. A. (1990). Psychological conditions of personal engagement and disengagement at work. Academy of Management Journal, $33,692-724$.

Locke, E. A. (1984). Job satisfaction. In M. Gruneberg \& T. Wall. (Eds.), Social psychology and organizational behaviour (pp. 92117). London, England: John Willey \& Sons.

Logan, George M. (1984). Loyalty and a sense of purpose. California Management Review, 27(1), 149-56.

Muthén, Bengt O., \& Linda K. Muthén. (1994). Mplus user's guide. Los Angeles: Muthén and Muthén.

Meyer, J. P., \& Allen, N. J. (1997). Commitment in the workplace: Theory, research, and application. Thousand Oaks: Sage Publications.

Morris, T., \& Empson, L. (1998). Organisation and expertise: An exploration of knowledge bases and the management of accounting and consulting firms. Accounting, Organizations and Society, 23(5/6), 609-624.

Michalos, A. C. (1981). Loyalty does not require illegality, immorality, or stupidity. National Forum, 61, 51-54.

Maslach, C., Schaufelli, W. B., \& Leiter, M. P. (2001). Job burnout. Annual Review of Psychology, 52, 397-422.

Moorman, Christine, Gerald Zaltman., \& Rohit Desphande. (1992). Relationships between providers and users of market research. Journal of Marketing Research, 29(3), 314-29.

20 IJMS 18 (2), 1-22 (2011) 
Meyer, J. P., \& Herscovitch, L. (2001). Commitment in the workplace: Toward a general model. Human Resource Management Review, 11, 299-326.

Morrow, P. C. (1983). Concept redundancy in organizational research: The case of work commitment. Academy of Management Review, 8, 486-500.

Meyer, J. P., Stanley, D. J., Herscovitch, L., \& Topolnytsky, L. (2002). Affective, continuance, and normative commitment to the organization: A meta-analysis of antecedents, correlates, and consequences. Journal of Vocational Behavior, 61(1), 20-52.

Rousseau, D. M. (1995). Psychological contracts in organizations: Understanding written and unwritten agreements. Thousand Oaks, CA: Sage Publications.

Roehling, P. V., Roehling, M. V., \& Moen, P. (2001). The relationship between work-life policies and practices and employee loyalty: A life course perspective. Journal of Family and Economic Issues, $22,141-170$.

Ringle, C. M., Sven, W., \& Alexander, W. (2005). Smart PLS 2.0. Retrieved from http://www.smartpls.de.

Rhoades, L., Eisenberger, R., \& Armeli, S. (2001). Affective commitment to the organization: The contribution of perceived organizational support. Journal of Applied Psychology, 86, 82536.

Sajeva, S. (2007). Identifying factors affecting motivation and loyalty of knowledge workers. Economics and Management, 643-652

Starbuck, W. (1992). Learning by knowledge-intensive firms. Journal of Management Studies, 29(6), 713-740.

Schalk, R., \& Freese, C. (1997). New facets of commitment in response to organizational change: Research trends and the dutch experience. In C.L. Cooper \& D.M. Rousseau (Eds.), Trends in organizational behavior (pp. 107-123). Chichester: John Wiley \& Sons.

Schaufeli, W. B., Salanova, M., Gonzalez-Roma, V., \& Bakker, A. B. (2002). The measurement of engagement and burnout: A two sample confirmatory factor analytic approach. Journal of Happiness Studies, 3, 71-92.

Sonnentag, S. (2003). Recovery, work engagement, and proactive behavior: A new look at the interface between non-work and work. Journal of Applied Psychology, 88, 518-28.

Schaufeli, W. B., \& Bakker, A. B. (2004). Job demands, job resources, and their relationship with burnout and engagement: A multisample study. Journal of Organizational Behavior, 25, 293-315.

Saks, A. M. (2006). Antecedents and consequences of employee engagement. Journal of Managerial Psychology, 21(7), 600-619.

IJMS 18 (2), 1-22 (2011) 21 
Tsui, A. S., Ashford, S. J.,Clair, L., \& Xin, K. R.(1995). Dealing with discrepant expectations: Response strategies and managerial effectiveness. Academy of Management Journal, 38, 1515-1543.

Tenenhaus, Michel.,Vincenzo Esposito Vinzi, Yves-Marie Chateline, \& Carlo Lauro. (2005). PLS path modeling. Computational Statistics and Data Analysis, 48(1), 159-205.

Vroom, Victor. (1964). Work and motivation. New York: John Wiley \& Sons.

Venetis, Karin A., \& Pervez N. Ghauri. (2004). Service quality and customer retention: Building long-term relationships. European Journal of Marketing, 38(11/12), 1577-98.

Welsch, H. P., \& LaVan, H. (1981). Inter-relationships between organizational commitment and job characteristics, job satisfaction, professional behavior, and organizational climate. Human Relations, 34, 1079-1089.

Wold, H. (1975). Path models with latent variables, the NIPALS approach. In H. M. Blalock, A. Aganbegian, F. M. Borodkin, R. Boudon, V. Cappecchi (Eds.), Quantitative Sociology (pp. 307353). International Perspectives on Mathematical and Statistical Modeling. New York: Academic Press.

Zen, X. C., Anne. S.Tsui, \& Jing-Lih Farh. (2002). Loyalty to supervisor vs. organizational commitment: Relationship to employee performance in China. Journal of Occupational and Organizational Psychology, 75, 339-356. 